\title{
Management of natural pasture increases native and exotic herbaceous biomass and biodiversity in the Caatinga of Brazil
}

\section{O manejo da pastagem natural incrementa a biomassa herbácea nativa e exótica e a biodiversidade na Caatinga no Brasil}

\author{
Jefte Arnon de Almeida Conrado ${ }^{1 *}$; Ana Clara Rodrigues Cavalcante ${ }^{2}$; Rafael \\ Gonçalves Tonucci²; Alan Rocha Saldanha³ ${ }^{3}$ Magno José Duarte Cândido ${ }^{4}$
}

\begin{abstract}
The objective of this study was to evaluate the ability of savanna thinning and enrichment with grasses to maintain local biodiversity and intensify biomass production in an area of Caatinga. The study was carried out in a Caatinga area thinned into savanna and an unmanipulated area during the rainy and rainy-dry transition seasons of 2016. The herbaceous biomass production, diversity, and equability of the thinned and unmanipulated areas were evaluated by calculating values of the Shannon-Weaver $\left(\mathrm{H}^{\prime}\right)$ and Pielou $\left(\mathrm{J}^{\prime}\right)$ indices. The establishment of massai and buffel grasses in the savanna-thinned area was also evaluated. The area thinned into savanna produced more native herbaceous forage biomass in both the rainy $\left(1,940.55 \mathrm{~kg} \mathrm{ha}^{-1}\right)$ and rainy-dry transition seasons $\left(1,918.55 \mathrm{~kg} \mathrm{ha}^{-1}\right)$ than that in the unmanipulated area in the same periods (78.42 and $37.40 \mathrm{~kg} \mathrm{ha}^{-1}$, respectively), without compromising biodiversity, as the Shannon-Weaver and Pielou indices for the savanna-thinned area $\left(\mathrm{H}^{\prime}=1.48\right.$ and $\mathrm{J}^{\prime}=0.62$, respectively) and for the unmanipulated area $\left(\mathrm{H}^{\prime}=1.29\right.$ and $\left.\mathrm{J}^{\prime}=0.72\right)$ were comparable. The frequency of species with a known forage value in the area thinned into savanna was still able to increase by $141 \%$ in the rainy season and $1,700 \%$ in the rainy-dry transition season. Massai grass became better-established in the savanna-thinned area that buffel grass, where it produced up to $3 \mathrm{t}$ of dry matter $\mathrm{ha}^{-1}$. The thinning and enrichment treatments promoted an increase in the biodiversity of the area, and moreover contributed to increases in forage biomass in the Caatinga.
\end{abstract}

Key words: Unmanipulated area. Massai grass. Buffel grass. Botanical composition. Enrichment. Savanna thinning.

\section{Resumo}

Objetivou-se avaliar o raleamento em savana e o enriquecimento com gramíneas em uma área de Caatinga mantendo a biodiversidade local e intensificando a produção de biomassa. Os estudos foram conduzidos numa Caatinga raleada em savana e numa área não manipulada no período chuvoso que foi dividido em duas épocas em 2016. Avaliaram-se a produção de biomassa herbácea, a diversidade e a equabilidade pelos índices de Shannon - Weaver (H') e de Pielou (J') das áreas raleada em savana e não manipulada. Foi ainda avaliado o estabelecimento dos capins massai e búffel na área raleada

\footnotetext{
1 Discente, Curso de Doutorado do Programa de Doutorado Integrado em Zootecnia, Universidade Federal do Ceará, Departamento de Zootecnia, UFC/UFRPE/UFPB, Fortaleza, CE, Brasil. E-mail: jefte arnon@hotmail.com

2 Pesquisadores, Empresa Brasileira de Pesquisa Agropecuária, EMBRAPA Caprinos e Ovinos, Sobral, CE, Brasil. E- mail: ana. clara.embrapa.br; rafael.tonucci@embrapa.br

3 Discente, Curso de Graduação em Zootecnia, Universidade Estadual Vale do Acaraú, UVA, Sobral, CE, Brasil. E-mail: rocha. alan80@gmail.com

4 Prof. Dr., Universidade Federal do Ceará, UFC, Fortaleza, CE, Brasil. E-mail: magno@ufc.br

* Autor para correspondência
} 
em savana. A área raleada em savana produziu mais biomassa de forragem herbácea nativa tanto na época das águas $\left(1.940,55 \mathrm{~kg} \mathrm{ha}^{-1}\right)$ quanto na época de transição águas-seca $\left(1.918,55 \mathrm{~kg} \mathrm{ha}^{-1}\right)$ do que a área não manipulada nas mesmas épocas (78,42 e 37,40 $\mathrm{kg} \mathrm{ha}^{-1}$, respectivamente), sem comprometer à biodiversidade, conforme os índices de Shannon-Weaver $\left(\mathrm{H}^{\prime}=1,48\right)$ e Pielou $\left(\mathrm{J}^{\prime}=0,62\right)$ para a área raleada em savana e H' $(1,29)$ e J' $(0,72)$, para a área não manipulada. A área raleada em savana foi ainda capaz de aumentar em $141 \%$ na época das águas e $1.700 \%$ na época de transição águas-seca, a frequência de espécies de conhecido valor forrageiro. O capim-massai apresentou melhor estabelecimento do que $\mathrm{o}$ capim-búffel, na área raleada em savana produzindo até $3 \mathrm{t} \mathrm{de} \mathrm{MS} \mathrm{ha}^{-1}$. O raleamento e o enriquecimento promovem um aumento da biodiversidade da área, além de contribuir para o incremento de biomassa de forragem.

Palavras-chave: Área não manipulada. Capim-massai. Capim-búffel. Composição botânica. Enriquecimento. Raleamento em savana.

\section{Introduction}

The Caatinga is located in one of the most densely populated semi-arid areas in the world. It is also one of the most important agricultural biomes in Brazil because it covers approximately $11 \%$ of the entire national territory and generates countless jobs (ALVES et al., 2009). However, the occurrence of periodic and increasingly long-lasting droughts is making plant production for agriculture in the Caatinga more vulnerable to reductions.

Livestock is therefore becoming fundamental for the development and growth of agriculture in this region, mainly because it is more resilient to drought. However, in the last few years it has been one of the main causes of environmental degradation in these areas in the world (LIMA et al., 2017). In the Caatinga, livestock production has been the leading cause of the extinction of native species, as it causes erosion, compaction, and diminished infiltration of water into the soil, and also contributes to the rural exodus (SILVA et al., 2018). As increasingly smaller and less productive areas remain available to farmers, the use of forage resources by them has been put under greater pressure, and without sustainable options deforestation has been used more and more intensively to provide for their forage needs (MENDES et al., 2013).

In the 1980s, techniques were developed in Brazil by Embrapa (the Brazilian Agricultural Research Corporation) to manipulate the Caatinga to increase its capacity to support forage crops and conservation
(SCHACHT; MALECHEK, 1989). Among the manipulation methods developed, thinning has been the most prominent for its capability to increase the diversity of herbaceous plant communities, as well as to promote increments greater than $76 \%$ in forage biomass production. This manipulation technique is characterized by the maintenance of a woody cover of $40 \%$ for pastoral purposes and $20 \%$ for agriculture (ARAÚJO FILHO et al., 2002).

However, no studies have been done that aimed to improve production with this thinning technique without compromising local biodiversity, and research on this topic in arid and semi-arid regions is still lacking (VEGA et al., 2017). In addition, some problems with these efforts have been identified, such as high labor costs, difficulty establishing grasses suitable for enrichment, and losses in the vigor of native plants. To solve some of these problems, adapted forage species have been inserted in some localities, with the aim to make production systems more feasible (CAMPANHA et al., 2011).

Buffel grass has been the forage grass most frequently used to enrich the Caatinga, mainly because it presents tolerance and adaptability to drought. However, such limitations as the low purity and germination of its seeds and its high competitive aggressiveness could compromise the persistence of native species in the Caatinga (MARSHALL et al., 2012). Recently, massai grass, which was initially developed for wetlands, has been identified as a 
promising candidate for use in the enrichment of semi-arid regions (CAVALCANTE et al., 2014).

Due to the above concerns, the objective of the present study was to evaluate the effects of savanna thinning and enrichment on the forage biomass production of the herbaceous strata of native and exotic plant species in the Caatinga and their biodiversity.

\section{Materials and Methods}

Two trials were carried out at Embrapa Goats and Sheep in Sobral, CE, Brazil, from January to June of 2016. The first trial was located in a Caatinga area thinned into savanna $\left(3^{\circ} 46^{\prime} 12.56^{\prime \prime} \mathrm{S}\right.$, $\left.40^{\circ} 19^{\prime} 40.94^{\prime \prime} \mathrm{W}\right)$ and an unmanipulated Caatinga area $\left(3^{\circ} 46^{\prime} 16.21^{\prime \prime} \mathrm{S}, 40^{\circ} 19^{\prime} 35.80^{\prime \prime} \mathrm{W}\right)$, and the second trial was done only in an area thinned into savanna at an altitude of $159 \mathrm{~m}$. The treated area was thinned in 1997, and covered approximately three hectares.
The climate in the experimental area is semiarid, of the BShw type according to the Köppen classification system, with a rainy season from January to June. The annual mean temperature is $28^{\circ} \mathrm{C}$, and the mean total annual precipitation is $759 \mathrm{~mm}$. The soils of the studied areas were a typical Arctic Cromic Luvisol and typical Arctic Hipocromic Luvisol, with a clayey texture (AGUIAR et al., 2014).

The chemical composition of the soil in the $0-10$ cm layer was as follows: $\mathrm{pH}=6.9$; organic matter (O.M.) $=31.5 \mathrm{~g} \mathrm{dm}^{-3} ; \mathrm{P}=11.1 \mathrm{mg} \mathrm{dm}^{-3} ; \mathrm{K}=200.8$ $\mathrm{mg} \mathrm{dm}{ }^{-3} ; \mathrm{Ca}=72.0 \mathrm{mmol}_{\mathrm{c}} \mathrm{dm}^{-3} ; \mathrm{Mg}=24.0 \mathrm{mmol}_{\mathrm{c}}$ $\mathrm{dm}^{-3} ; \mathrm{H}+\mathrm{Al}=15.0 \mathrm{mmol}_{\mathrm{c}} \mathrm{dm}^{-3} ; \mathrm{B}=101.0 \mathrm{mmol}_{\mathrm{c}}$ $\mathrm{dm}^{-3} ; \mathrm{CEC}=116.0 \mathrm{mmol}_{\mathrm{c}} \mathrm{dm}^{-3}$; and $\mathrm{V}=87.0 \%$. The fertility of the soil exempted us from needing to carry out fertilization practices at the time of the experiment. The climatic data for the studied areas (temperature (maximum, average, and minimum), dew point, and weekly cumulative precipitation) are presented in Figure 1.

Figure 1. Maximum, average, and minimum temperature $\left({ }^{\circ} \mathrm{C}\right)$, dew point $\left({ }^{\circ} \mathrm{C}\right)$, and weekly cumulative precipitation $(\mathrm{mm})$ at the experimental site in the year 2016.

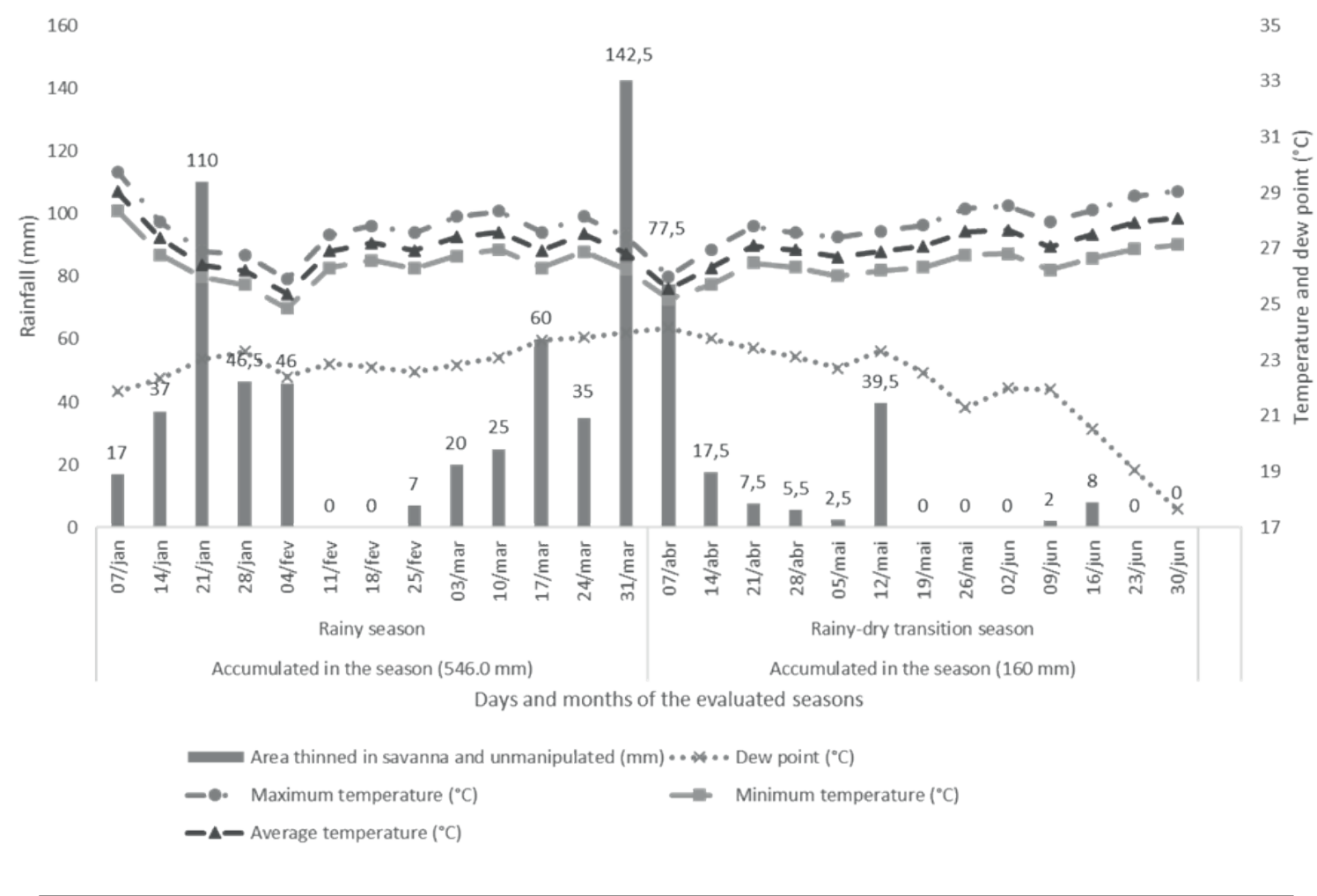




\section{Trial 1}

The following treatments were implemented: Caatinga areas were either thinned into savanna or left as unmanipulated Caatinga (control). The phytosociological, botanical, and structural characteristics of the herbaceous and woody strata were evaluated in the area thinned into savanna and the control area in two seasons, the rainy (January 1 to March 31, 2016) and rainy-dry transition (April 1 to June 30, 2016) seasons, as shown in Figure 2.

Figure 2. Savana-thinned (A) and unmanipulated (B) areas in the rainy season; savanna-thinned (C) and unmanipulated (D) areas in the rainy-dry transition season; and buffel grass (E) and massai grass (F) managed in the Caatinga area thinned into savanna.

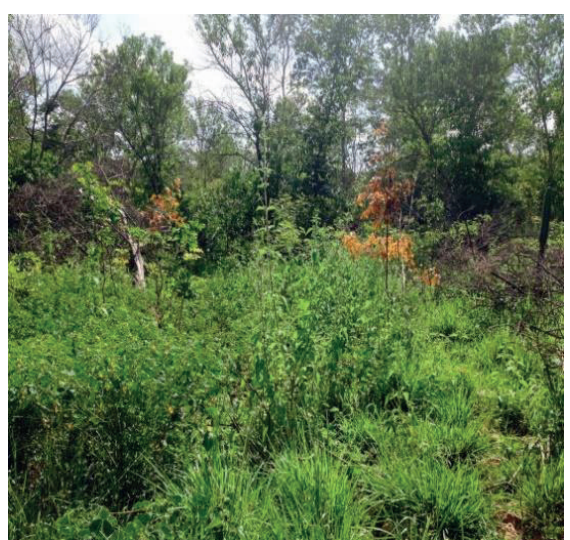

(A)

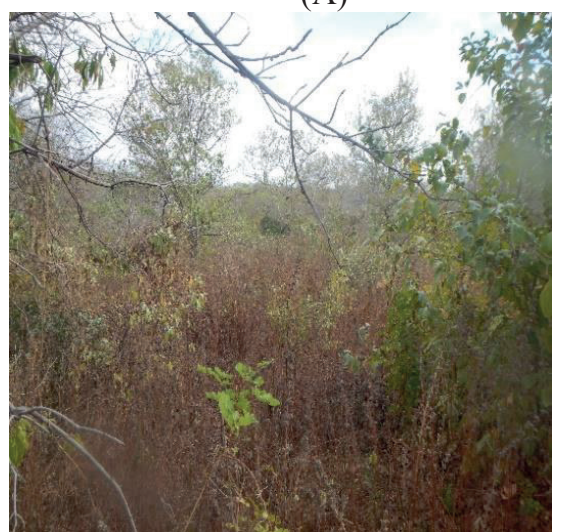

(C)

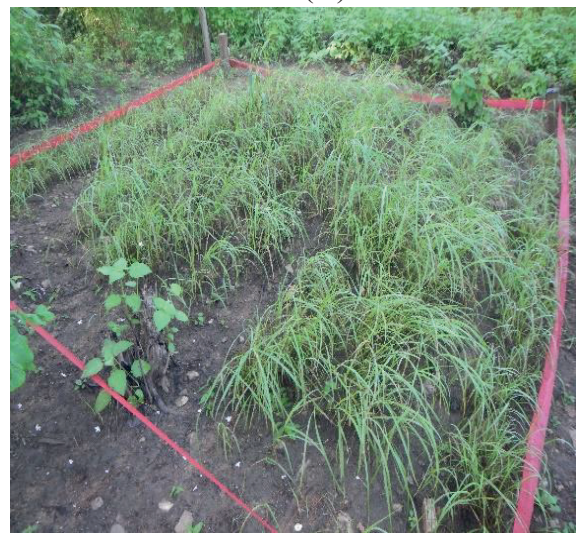

(E)

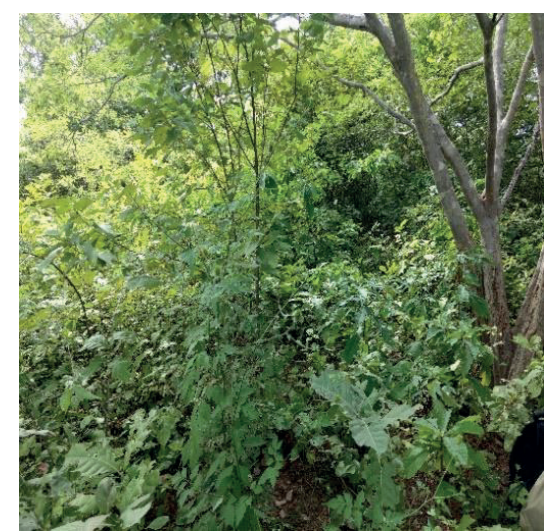

(B)

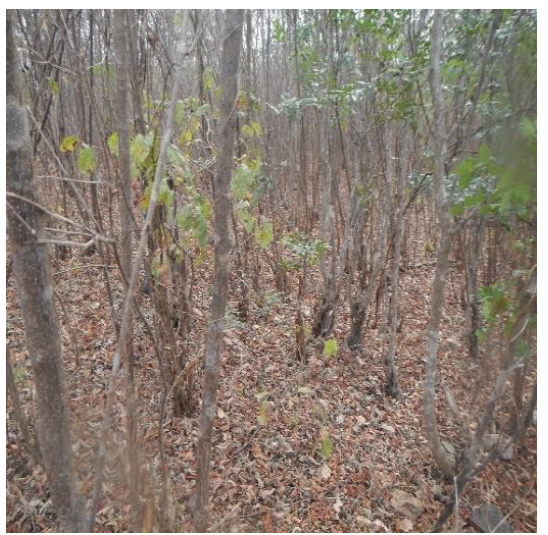

(D)

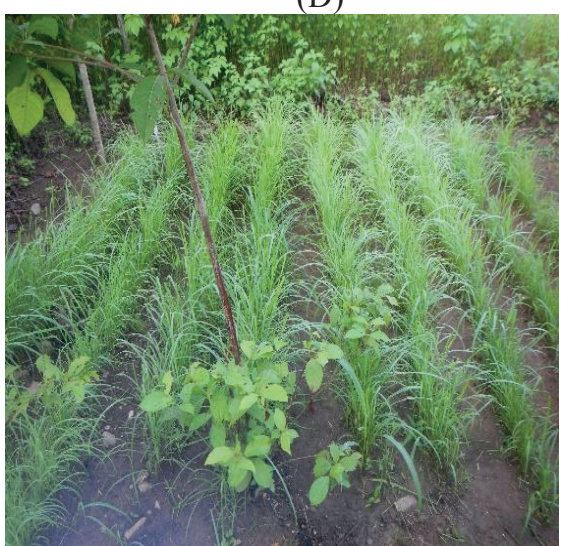

(F) 
The experimental design adopted consisted of completely randomized blocks in a split-plot arrangement, with repeated measures through time; the plots were the areas thinned into savanna and the control areas, and the subplots were the seasons (rainy and rainy-dry transition), with four replicates each. Each block represented a quarter of the total area, and thus allowed us to collect a significant number of samples throughout the area and meet the standards of analysis of variance.

The herbaceous and woody strata were evaluated separately. The herbaceous stratum was considered to be composed of all the species inside a $0.250 \mathrm{~m}^{2}$ frame and under $1 \mathrm{~m}$ tall, while the woody stratum was considered to be composed of shrubs and trees whose height was greater than $1.0 \mathrm{~m}$ and that had a diameter at ground level (DGL) of more than 3 cm (RODAL et al., 2013). The phytosociological characteristics evaluated were the density, cover, and frequency of each herbaceous and woody species. For the herbaceous stratum, the total soil coverage (\%), mono- and dicotyledonous coverage $(\%)$, litter (\%), and absolute density (\%) were evaluated visually. Further, diversity (ShannonWeaver, $\mathrm{H}^{\prime}$ ) and equability (Pielou, $\mathrm{J}^{\prime}$ ) indices were also calculated.

The equations of these indices (1-6) are presented below:

$$
\text { A. F. }(\%)=\frac{\text { n.s.s }}{\text { T.N.S. }} \times 100,(1)
$$

where A.F. is the absolute frequency, n.s.s. is the number of sample units in which the species under consideration occurred, and T.N.S. is the total number of sample units; and:

$$
\text { S. D. }\left(\frac{\text { indivídual }}{\text { ha }}\right)=\frac{10.000}{\mathrm{Ax} \mathrm{N}} \text {, }
$$

where S.D corresponds to the specific density of the species under consideration, $\mathrm{A}$ is the area sampled, and $\mathrm{N}$ the total number of individuals sampled. Further:

$$
\text { R. D. }(\%)=\frac{\text { S.D. }}{\text { T.D. }}
$$

where R.D. is the relative density, S.D. is the specific density, and T.D. is the total density of a species;

$$
\text { T. D. }\left(\frac{\text { plants }}{\text { ha }}\right)=\sum S . \text { D., (4) }
$$

where T.D. is the total density and S.D. is the specific density of a species; and:

$$
\mathrm{H}^{\prime}=-\sum_{\mathrm{i}=1}^{\mathrm{s}} \frac{\mathrm{ni}}{\mathrm{N}} \times \ln \frac{\mathrm{ni}}{\mathrm{N}},(5)
$$

where $\mathrm{H}^{\prime}$ is the value of the diversity index of Shannon-Weaver $\left(\mathrm{H}^{\prime}\right)$, n.i. is the number of individuals sampled of the $i^{\text {th }}$ species, $\mathrm{N}$ is the total number of individuals sampled, and $\ln$ is the neperian logarithm. Lastly:

$$
\mathrm{J}^{\prime}=\frac{\mathrm{H}^{\prime}}{\ln (\mathrm{S})},(6)
$$

where $\mathrm{J}^{\prime}$ corresponds to the equability index of Pielou, $\mathrm{H}^{\prime}$ is the diversity index of ShannonWeaver, $\ln$ is the neperian logarithm, and (S) is the total number of species sampled.

To identify the botanical composition of plant species in the experimental areas, plants were collected, herborized, and identified according to the protocol of the APG III system (ANGIOSPERM PHYLOGENY GROUP, 2009). From the botanical composition data, the species were grouped into forage plants (those recognized to be accepted by animals) and non-forage plants (invasive, toxic, and low-nutritive plants). The identified species were given a number according to their order of collection within this research project, and then registered in the herbarium of Embrapa Goats and Sheep.

Structural variables of the native pasture, mainly of the herbaceous stratum, were quantified, among which we determined: the total forage biomass $\left(\mathrm{kg} \mathrm{ha}^{-1}\right)$ and litter biomass $\left(\mathrm{kg} \mathrm{ha}^{-1}\right)$ inside a 0.25 $\mathrm{m} \times 1.0 \mathrm{~m}\left(0.250 \mathrm{~m}^{2}\right)$ frame; height $(\mathrm{cm})$, which was measured using a retractable graduated rod adapted from the sward stick type (BARTHRAM, 1986); and leaf area index (LAI) and interception of photosynthetically active radiation (IPAR, \%), which were measured using the Accupar LP-80 model PAR-LAI analyzer for agriculture, with readings taken below and above the herbaceous canopy at a minimum of 12 points each in both the area of the Caatinga thinned into savanna and the 
control area.

For the woody stratum, the variables measured were: the diameter at height of the base (DB) at 0.30 $\mathrm{m}$ from the ground; diameter at breast height (DBH) at $1.3 \mathrm{~m}$ from the ground; and height $(\mathrm{m})$ of the trees present in $15 \mathrm{~m} \mathrm{x} 30 \mathrm{~m}\left(450 \mathrm{~m}^{2}\right)$ plots, all of which were measured using a Finn caliper.

\section{Trial 2}

The enrichment of the Caatinga area thinned into savanna was evaluated in terms of the establishment of massai grass (Megathyrsus maximus cv. Massai syn. Panicum maximum cv. Massai) and buffel grass (Pennisetum ciliare syn. Cenchrus ciliares cv. Áridus), as shown in Figure 2.

The cultural value (which for the massai grass was 21 and for the buffel grass was 1.2) (7), was a pre-requirement for calculating the recommended minimum sowing rate ( $\mathrm{kg}$ of seeds $\left.\mathrm{ha}^{-1}\right)(8)$. These values were used in the following equations:

$$
\text { C.V. }(\%)=\frac{P}{G} \times 100,(7)
$$

where C.V. is the cultural value, $\mathrm{P}$ is the purity of the seeds, and $\mathrm{G}$ is the germination rate; and:

$$
\text { M. S. R. }(\mathrm{kg} / \mathrm{ha})=\frac{\text { P.C.V. }}{\% \text { C.V. }},(8)
$$

where M.S.R. is the minimum sowing rate, P.V.C is the points of cultural value, and C.V. is the cultural value.

Planting of the two grasses was performed in rows spaced $35 \mathrm{~cm}$ apart in $3 \mathrm{~m} \times 3 \mathrm{~m}\left(9 \mathrm{~m}^{2}\right)$ plots, to a depth of $2 \mathrm{~cm}$ for the massai grass and $3 \mathrm{~cm}$ for the buffel grass. Seedlings were fertilized with a dose of $67 \mathrm{~g} \mathrm{plot}^{-1}$, equivalent to $300 \mathrm{~kg} \mathrm{ha}^{-1}$ of $\mathrm{N}$, with urea as the nitrogen source, at 16 days post-germination using low technological level conditions (COMISSÃO DE FERTILIDADE DO SOLO DO ESTADO DE MINAS GERAIS, 1999). To evaluate the establishment of these grasses, various physiological and structural variables were quantified. The experimental design was completely randomized with four replicates, with the plots
( $3 \mathrm{~m} \times 3 \mathrm{~m}$ ) in which the grasses were cultivated considered as the experimental units. However, for each variable, the minimum acceptable number of plants was analyzed that was needed to represent the experimental units and meet the requirements of analysis of variance.

Data for the different variables were collected 60 days after germination (LOPES et al., 2014). Two devices were used: a LC-Pro-SD model infrared gas exchange analyzer (IRGA) and a SPAD-502 model chlorophyllometer. Measurements were performed on the last newly expanded leaf of the plants located in an intermediate growing position within the plot. The day before these measurements, a daily round of measurements was made at 06:00, 08:00, 10:00, $12: 00,14: 00$, and 16:00 to determine the maximum photosynthetic rate, which was determined to occur at 10:00. The variables for which data were collected were: leaf transpiration rate $\left(\mathrm{E}, \mathrm{mmol} \mathrm{m}^{-2}\right.$ $\left.\mathrm{s}^{-1}\right)$; photosynthetic rate $\left(\mathrm{A}, \mu \mathrm{mol} \mathrm{m} \mathrm{m}^{-2} \mathrm{~s}^{-1}\right)$; stomatal conductance ( $\left.\mathrm{gs}, \mathrm{mol} \mathrm{m}^{-2} \mathrm{~s}^{-1}\right)$; internal concentration of carbon dioxide ( $\mathrm{Ci}$, ppm); internal leaf temperature $\left(\mathrm{T}_{\text {leaf }},{ }^{\circ} \mathrm{C}\right)$; rate of carboxylation $(\mathrm{A} / \mathrm{Ci})$; intrinsic water use efficiency (A/E); and chlorophyll relative index (SPAD units).

The evaluation of the structural parameters occurred 80 days post-germination, when the establishment cut was made and the following variables were quantified: total biomass ( $\mathrm{kg}$ of dry matter per hectare) and its fractions (leaf blade, stem, and dead material, in $\mathrm{kg} \mathrm{ha}^{-1}$ ) cut at ground level; the population density of tillers (PDT, plants $\left.\mathrm{m}^{-2}\right)$ within a $0.5 \mathrm{~m} \times 0.5 \mathrm{~m}\left(0.25 \mathrm{~m}^{2}\right)$ frames; height $(\mathrm{cm})$, LAI, and IPAR (\%), measured using the Accupar LP-80 model PAR-LAI analyzer equipment for agriculture, with readings taken below and above the canopy of the massai grass and the buffel grass; and number of live leaves per tiller (NLL). The rainfall use efficiency (RUE) was also quantified, and expressed in $\mathrm{kg} \mathrm{ha}^{-1} \mathrm{~mm}^{-1}$, according to the equation of TURNER (2004) (9):

$$
R U E=\frac{T F B}{A R},(9)
$$


where TFB is the total forage biomass and AR is the accumulated rainfall.

All data were assessed for normality with the Shapiro-Wilk's test $(\mathrm{P}<0.05)$, and for homoscedasticity with the Bartlett's test $(\mathrm{P}<0.05)$. The structural and physiological characteristics' data were submitted to analysis of variance (ANOVA). Interactions were interpreted when they were found to be significant by the F-test $(\mathrm{P}<0.05)$, and means were compared using the Tukey's test $(\mathrm{P}<0.05)$. The number of live leaves per tiller (NLL) data from Trial 2 were transformed to meet assumptions of ANOVA by the equation: $\mathrm{Y}^{\prime}=\mathrm{y}^{-}$ ${ }^{2}$. Descriptive statistics were also calculated for the phytosociological and botanical composition parameters. As a tool for statistical analysis, the MIXED procedure of the software SAS version 9.3 (SAS INSTITUTE, 2005) was used, treating both the manipulation of the Caatinga and exotic species as fixed effects.

\section{Results and Discussion}

Trial 1

The thinning of the Caatinga into savanna stimulated the emergence of herbaceous species in both the rainy and rainy-dry transition seasons (Table 1), opening the potential for the emergence of new species. According to Aguiar et al. (2013), increases in floral biodiversity in semi-arid and arid environments promote greater sustainability in these regions, which are characterized mainly by low precipitation and biomass production and high temperatures, to introductions.

For the period of lower rainfall (rainy-dry transition) (Figure 1) in the area thinned into savanna, 14 species were identified, with Phaseolus patyroides Linnaeus standing out with a frequency of $20.8 \%$. This is a forage species of great nutritional value, which can be used in animal feeding (PEREIRA FILHO et al., 2013). For the control area, 3 species were identified in the same season, with Senna obtusifolia Link. Irwin \& Barneby found with a frequency of $100 \%$. According to Pereira Filho et al. (2007), this species is an annual herbaceous legume that is very common in dry periods, but is not accepted well by animals.

Table 1. Botanical identification (family and scientific name) and absolute frequency (A.F., \%) of species of the herbaceous stratum in two seasons (rainy and rainy-dry transition); and absolute frequency (A.F. \%), specific density (S.D, individuals ha ${ }^{-1}$ ), and total density (individuals ha ${ }^{-1}$ ) of species of the woody stratum in the rainy season in the Caatinga area thinned into savanna (Thin.) and the unmanipulated control area (Contr.) in Sobral, CE in 2016.

\begin{tabular}{|c|c|c|c|c|c|c|}
\hline \multirow{3}{*}{ Famíly } & \multirow{3}{*}{$\mathrm{N}^{\circ}$} & \multirow{3}{*}{ Scientific name } & \multicolumn{4}{|c|}{ A.F. $(\%)$} \\
\hline & & & \multicolumn{2}{|c|}{ Rainy } & \multicolumn{2}{|c|}{ Rainy-dry trans. } \\
\hline & & & Thin. & Contr. & Thin. & Contr. \\
\hline \multicolumn{7}{|c|}{ Herbaceous stratum } \\
\hline Asteraceae & 01 & Bidens pilosava. Minor Blume Sherff. & 2.10 & 5.00 & 8.30 & 0.00 \\
\hline Costaceae & 02 & Costus spiralis. Jacq & 2.10 & 0.00 & 0.00 & 0.00 \\
\hline Commelinaceae & $03^{\ddagger}$ & Commelina nudiflora Linnaeus & 0.00 & 6.70 & 6.20 & 0.00 \\
\hline Convolvulaceae & 04 & Ipomoea asarifolia Desr. Roem. \& Schult & 12.50 & 15.00 & 0.00 & 0.00 \\
\hline Convolvulaceae & $05^{\ddagger}$ & Jacquemontia gracillima Choisy. Hallierf. & 0.00 & 36.70 & 0.00 & 0.00 \\
\hline Combretaceae & $06^{\ddagger}$ & Combretum leprosum Martius & 0.00 & 3.30 & 0.00 & 0.00 \\
\hline
\end{tabular}


continuation

\begin{tabular}{|c|c|c|c|c|c|c|}
\hline Euphorbiaceae & 07 & Croton sonderianus Muell.Arg & 2.10 & 11.70 & 0.00 & 0.00 \\
\hline Euphorbiaceae & 08 & Cnidoscolus urens Link. Arthur & 4.10 & 0.00 & 0.00 & 0.00 \\
\hline Equisetaceae & 09 & Equisetum hyemale Lehm. & 13.50 & 1.70 & 0.00 & 0.00 \\
\hline Fabaceae & $10^{\ddagger}$ & Arachis dardani Krapov. \& Wing. Coutu. Gregory & 64.60 & 8.30 & 2.00 & 0.00 \\
\hline Fabaceae & $11^{\ddagger}$ & Canavalia brasiliensis Mart. Benth. & 10.40 & 21.70 & 0.00 & 0.00 \\
\hline Fabaceae & $12^{\ddagger}$ & Cajanus cajan Link Millsp & 9.40 & 0.00 & 0.00 & 0.00 \\
\hline Fabaceae & $13^{+}$ & Poincianella pyramidalis Tui. & 6.20 & 0.00 & 4.20 & 0.00 \\
\hline Fabaceae & $14^{\ddagger}$ & Mimosa caesalpiniaefolia Benth. & 4.10 & 0.00 & 4.20 & 0.00 \\
\hline Fabaceae & $15^{\ddagger}$ & Mimosa modesta Martius. & 4.20 & 0.00 & 0.00 & 0.00 \\
\hline Fabaceae & $16^{\ddagger}$ & Mimosa tenuiflora Wild. Poir. & 33.30 & 0.00 & 8.30 & 0.00 \\
\hline Fabaceae & $17^{\ddagger}$ & Phaseolus patyróides Linnaeus & 0.00 & 0.00 & 20.80 & 2.10 \\
\hline Fabaceae & 18 & Senna obtusifolia Link. Irwin \& Barneby & 24.00 & 75.00 & 16.70 & 100.00 \\
\hline Fabaceae & $19^{\ddagger}$ & Stylosanthes spp & 0.00 & 3.30 & 4.20 & 0.00 \\
\hline Fabaceae & 20 & Senna trachypus Benth. Irwin \& Barneby & 0.00 & 1.70 & 0.00 & 0.00 \\
\hline Hypoxidaceae & 21 & Hypoxis decumbens Lehm & 33.30 & 5.00 & 0.00 & 0.00 \\
\hline Lamiaceae & 22 & Hyptis suaveolens Link Poit. & 91.70 & 25.00 & 95.80 & 2.10 \\
\hline Malvaceae & 23 & Herissantia tiubae Schum. Brizicky & 0.00 & 0.00 & 6.20 & 0.00 \\
\hline Malvaceae & 24 & Wissadula spicata Kunth. C.Presl & 8.30 & 41.70 & 0.00 & 0.00 \\
\hline Oxalidaceae & 25 & Oxalis glaucescens Norl. & 60.40 & 3.30 & 0.00 & 0.00 \\
\hline Poaceae & $26^{\ddagger}$ & Anthephora Hermaphrodita Link. Kuntze & 35.40 & 0.00 & 0.00 & 0.00 \\
\hline Poaceae & $27^{\ddagger}$ & Brachiaria plantaginea Link. Hitchc & 79.20 & 21.70 & 0.00 & 0.00 \\
\hline Portulacaceae & 28 & Portulaca oleracea Linnaeus & 10.40 & 6.70 & 2.10 & 0.00 \\
\hline Rubiaceae. & 29 & Borreria verticillata L. G.Mey & 0.00 & 0.00 & 4.20 & 0.00 \\
\hline Verbenaceae & 30 & Lantana camara Linnaeus. & 97.90 & 63.30 & 2.00 & 0.00 \\
\hline Verbenaceae & 31 & Lippia alba Mill. Brown & 10.40 & 1.70 & 0.00 & 0.00 \\
\hline & & Woody stratum & \multicolumn{2}{|c|}{ A.F $(\%)$} & \multicolumn{2}{|c|}{ S.D (individuals ha ${ }^{-1}$ ) } \\
\hline & & & Thin. & Contr & Thin. & Contr. \\
\hline Anacardiaceae & $32^{\ddagger}$ & Myracrodruon urundeuva Allemão & 100.00 & 0.00 & 4.00 & 0.00 \\
\hline Boraginaceae & $33^{\ddagger}$ & Cordia oncocalyx Allemão & 100.00 & 100.00 & 105.00 & 33.00 \\
\hline Combretaceae & $34^{\ddagger}$ & Combretum leprosum Martius & 100.00 & 100.00 & 4.00 & 94.00 \\
\hline Euphorbiaceae & 35 & Croton sonderianus Mull. Arg & 100.00 & 100.00 & 1.00 & 628.00 \\
\hline Euphorbiaceae & $36^{\ddagger}$ & Manihot glaziovii Mull. Arg & 100.00 & 0.00 & 1.00 & 0.00 \\
\hline Fabaceae & 37 & Anadenanthera colubrina Vell Brenam & 100.00 & 0.00 & 14.00 & 0.00 \\
\hline Fabaceae & 38 & Amburana cearensis Allemão.Smith & 100.00 & 0.00 & 2.00 & 0.00 \\
\hline Fabaceae & 39 & Dioclea virgata Rich. & 100.00 & 0.00 & 8.00 & 0.00 \\
\hline Fabaceae & $40^{\ddagger}$ & Mimosa tenuiflora Willd. Poir & 100.00 & 100.00 & 2.00 & 50.00 \\
\hline Fabaceae & $41^{\ddagger}$ & Mimosa Caesalpinifolia Benth & 100.00 & 100.00 & 20.00 & 83.00 \\
\hline Fabaceae & $42^{\ddagger}$ & Poincianella pyramidalis Tui. & 100.00 & 100.00 & 21.00 & 211.00 \\
\hline \multicolumn{5}{|c|}{ Total density (individuals ha ${ }^{-1}$ ) } & 182.00 & $1,099.00$ \\
\hline
\end{tabular}

Identification number given to each species according to the alphabetical order of its family $\left(\mathrm{N}^{\circ}\right)$ in this study.

${ }^{\ddagger}$ Forage species. 
The savanna thinning treatment provided an environment for herbaceous plants that favored the best use of such abiotic factors as light, temperature, and humidity by them, which improved the performance of their photosynthetic processes, especially in forage plants (Table 1). According to Campelo et al. (2015), low water availability and humidity, high temperature, and/or high coverage of the woody stratum, affects the photochemical and biochemical reactions that are directly linked to stomatal closure. This increase in the savannathinned area was especially large in plants of the family Fabaceae, while in the control area this number was lower (Table 2). According to Freitas et al. (2011), the soils of semiarid regions are poor in nitrogen, and the emergence of fabaceaen plants becomes fundamental to the sustainability of production systems there because, besides fixing nitrogen, these species also have high levels of crude protein. Another factor is the protection generated for the soil against climatic adversities. Removal of pre-existing vegetation in semi-arid regions reduces soil porosity and density, leading to impaired soil water infiltration, which compromises the appearance of native species (SILVA et al., 2018).

Table 2. Functional groups (forage and non-forage species) of the herbaceous and woody stratums of the Caatinga area thinned into savanna (Thinned) and the unmanipulated area (Control) in Sobral, CE in the rainy season of 2016.

\begin{tabular}{|c|c|c|c|c|c|c|}
\hline \multirow{3}{*}{ Functional group } & \multirow{3}{*}{ Family } & \multirow{3}{*}{$\begin{array}{l}\text { Identification } \\
\mathrm{N}^{o} \text { of the herba- } \\
\text { ceous species }\end{array}$} & \multicolumn{4}{|c|}{$\begin{array}{l}\text { Minimum and maximum absolute frequency variation } \\
(\%) \text { of the herbaceous stratum }\end{array}$} \\
\hline & & & \multicolumn{2}{|c|}{ Rainy season } & \multicolumn{2}{|c|}{$\begin{array}{l}\text { Rainy-dry transition sea- } \\
\text { son }\end{array}$} \\
\hline & & & Thinned & Control & Thinned & Control \\
\hline \multirow{5}{*}{ Herbaceous forage } & Commelinaceae & 03 & $0-0$ & $0-6.70$ & $0-6.20$ & $0-0$ \\
\hline & Convolvulaceae & 05 & $0-0$ & $0-36.70$ & $0-0$ & $0-0$ \\
\hline & Combretaceae & 06 & $0-0$ & $0-3.30$ & $0-0$ & $0-0$ \\
\hline & Fabaceae & 10 to 17 and 19 & $0-64.6$ & $0-21.70$ & $0-20.80$ & $0-2.10$ \\
\hline & Poaceae & 26 and 27 & $35.40-79.20$ & $0-21.70$ & $0-0$ & $0-0$ \\
\hline \multirow{13}{*}{$\begin{array}{l}\text { Non-herbaceous } \\
\text { forage }\end{array}$} & Asteraceae & 01 & $0-2.10$ & $0-5.00$ & $0-8.30$ & $0-0$ \\
\hline & Costaceae & 02 & $0-2.10$ & $0-0$ & $0-0$ & $0-0$ \\
\hline & Convolvulaceae & 04 & $0-12.50$ & $0-15.00$ & $0-0$ & $0-0$ \\
\hline & Euphorbiaceae & 07 and 08 & $2.10-4.10$ & $0-11.70$ & $0-0$ & $0-0$ \\
\hline & Equisetaceae & 09 & $0-13.50$ & $0-1.70$ & $0-0$ & $0-0$ \\
\hline & Fabaceae & 18 and 20 & $0-24.00$ & $1.7-75$ & $0-16.70$ & $0-100.00$ \\
\hline & Hypoxidaceae & 21 & $0-33.30$ & $0-5.00$ & $0-0$ & $0-0$ \\
\hline & Laminaceae & 22 & $0-91.70$ & $0-25.00$ & $0-95.80$ & $0-2.10$ \\
\hline & Malvaceae & 23 and 24 & $0-8.3$ & $0-41.70$ & $0-6.20$ & $0-0$ \\
\hline & Oxalidaceae & 25 & $0-60.40$ & $0-3.30$ & $0-0$ & $0-0$ \\
\hline & Portulaceae & 28 & $0-10.40$ & $0-6.70$ & $0-2.10$ & $0-0$ \\
\hline & Rubiaceae & 29 & $0-0$ & $0-0$ & $0-4.20$ & $0-0$ \\
\hline & Verbenaceae & 30 and 31 & $10.40-97.90$ & $1.7-63.30$ & $0-2.00$ & $0-0$ \\
\hline
\end{tabular}

continue 
continuation

\begin{tabular}{|c|c|c|c|c|}
\hline \multirow[t]{2}{*}{ Functional group } & \multirow[t]{2}{*}{ Family } & \multirow{2}{*}{$\begin{array}{c}\text { Identification } \\
\mathrm{N}^{\circ} \text { of the woody } \\
\text { species }\end{array}$} & \multicolumn{2}{|c|}{$\begin{array}{l}\text { Minimum and maximum absolute frequency variation } \\
(\%) \text { of the woody stratum }\end{array}$} \\
\hline & & & Thinned & Control \\
\hline \multirow{5}{*}{ Woody forage } & Anacardiaceae & 32 & $0-100.00$ & $0-0$ \\
\hline & Boraginaceae & 33 & $0-100.00$ & $0-100.00$ \\
\hline & Combretaceae & 34 & $0-100.00$ & $0-100.00$ \\
\hline & Euphorbiaceae & 36 & $0-100.00$ & $0-0$ \\
\hline & Fabaceae & 40 to 42 & $0-100.00$ & $0-100.00$ \\
\hline \multirow[t]{2}{*}{ Non-woody forage } & Euphorbiaceae & 35 & $0-100.00$ & $0-100.00$ \\
\hline & Fabaceae & 37 to 39 & $0-100.00$ & $0-0$ \\
\hline
\end{tabular}

Identification number were given to the species according to the alphabetical order of their family in Table $1\left(\mathrm{~N}^{\circ}\right)$.

The species of the family Fabaceae that occurred with the highest frequency in the savanna-thinned area in the rainy season was Arachis dardani Krapov. \& Wing. Coutu. Gregory, and in the rainydry transition season the most abundant species was Phaseolus patyroides Linnaeus, while in the control area only the latter of these species was found. These species are classified as forage, and have good nutritional value. This demonstrates that thinning, through its effects on percent woody coverage, was able of keep the coverage and density of non-forage species down in a way that did not interfere with the growth and development of forage species. According to Souza et al. (2010), light and temperature are the main propellants for the germination of species in the Caatinga other than humidity.

Among all the herbaceous species identified, the one that was found at the highest frequency in both the savanna-thinned area and in the control area during the rainy season was Lantana Camará Link., with frequencies from $97.9 \%$ to $63.3 \%$ in the rainy season but reduced to $2 \%$ and $0 \%$ in the rainy-dry transition season. In the rainy-dry transition season in the savanna-thinned area, the species Hyptis suaveolens Link. Poit and Senna obtusifolia Link Irwin and Barneby, with occurrence frequencies of $95.8 \%$ and $100 \%$, respectively, in the control area, were the ones found at the highest frequency there. Reductions in precipitation and increases in temperature activate the flowering of most of the herbaceous species of the Caatinga, favoring their reproductive phenology, which contributes to their rapid disappearance (ARAÚJO et al., 2011).

Among the families of the woody stratum, the presence of Anacardiaceae was only detected in the savanna-thinned area, and the species Myracrodruon urundeuva Allemão presented the highest number of trees there (Table 1).

The thinning of the savanna area promoted an increase in the frequency of herbaceous forage species of $141 \%$ in the rainy season and $1,700 \%$ in the rainy-dry transition season when compared to the control area. The frequency of forage species of the family Poaceae presented a minimum variation of $35.4 \%$ and a maximum variation of $79.2 \%$ in their A.F. (Table 2). Out of the species in this family, Anthephora hermaphrodita Link. Kuntze was the one with the highest absolute frequency. This species is an annual that is highly appreciated by animals; its development is stimulated by the solar radiation that favors the germination of its seeds, causing greater tillering with less coverage (SILVA et al., 2011).

It should also be mentioned is that the increased biodiversity in the thinned area can contribute to countless other benefits in the short and long term. 
According to Tilman et al. (1997), an increase in the number of species contributes to reductions in the nitrate in the soil, which may lead to future environmental problems.

For the variables that attested to the diversity (Shannon-Weaver, $\mathrm{H}^{\prime}$ ) and equability (Pielou, $\mathrm{J}^{\prime}$ ) of the plant community, the thinned area presented values close to those of the control area. These indices and their similar values showed that savanna thinning maintains local diversity at a level similar to that of an area without exploitation (native), contributing to its sustainability. Differences between treatments were observed $(\mathrm{P}<0.05)$ in the structural variables DB, DBH, and height of the woody stratum (Table 3), with the area thinned into savanna presenting the highest values. These higher values are possibly associated with the low density of the woody stratum in the savanna-thinned area (Table 1), which contributed to an increase in woody growth over the years.

Table 3. Structural variables (DB, DBH, and height) and Shannon-Weaver $\left(\mathrm{H}^{\prime}\right)$ and Pielou $\left(\mathrm{J}^{\prime}\right)$ indices of the woody stratum in the Caatinga area thinned into savanna (Savanna thinned) and the unmanipulated area (Control) in Sobral, CE in 2016.

\begin{tabular}{|c|c|c|}
\hline Variables & Savanna-thinned & Control \\
\hline \multicolumn{3}{|c|}{ Diversity and equability indices } \\
\hline $\mathrm{H}^{\prime}$ & 1.48 & 1.29 \\
\hline $\mathrm{J}^{\prime}$ & 0.62 & 0.72 \\
\hline \multicolumn{3}{|c|}{ Structural variables } \\
\hline $\mathrm{DB}(\mathrm{cm})$ & $18.60^{\mathrm{a}}$ & $5.96^{\mathrm{b}}$ \\
\hline $\mathrm{DBH}(\mathrm{cm})$ & $11.20^{\mathrm{a}}$ & $3.30^{\mathrm{b}}$ \\
\hline Height (m) & $5.00^{\mathrm{a}}$ & $2.80^{\mathrm{b}}$ \\
\hline
\end{tabular}

Means followed by different letters in the same row for each structural variable significantly differed according to Tukey's test $(\mathrm{p}<0.05)$.

Abbreviations: diameter at base height (DB, cm) and diameter at breast height $(\mathrm{DBH}, \mathrm{cm})$.

When a significant effect was detected, the letters are presented to the left of the means in the table.

The thinning of the area into savanna favored increases in forage biomass $(\mathrm{P}<0.05)$ in both the rainy and rainy-dry transition seasons. This response was mainly due to the increase $(\mathrm{P}<0.05)$ in the growth of herbaceous dicotyledonous plants by $45.2 \%$ in the rainy season and $39.6 \%$ in the rainydry transition season, as well as that of herbaceous monocotyledons, especially in the rainy season (Table 4).

A significant interaction between treatment and season was observed $(\mathrm{P}<0.05)$ for the variable total soil coverage, with the rainy season having the highest mean values and the rainy-dry transition season the lowest, but there was only a significant difference $(\mathrm{P}<0.05)$ between the rainy and rainy-dry transition seasons. These responses were due to the reduced rainfall over the evaluated seasons (Figure 1) and the presence of a more favorable environment for herbaceous species offered by savanna thinning, mainly because it maintains a coverage of $40 \%$.

There was a significant effect $(\mathrm{P}<0.05)$ on the variable coverage by herbaceous monocotyledons in the savanna-thinned area. Savanna thinning promoted better light conditions for these species, presenting an average IPAR of $87 \%$, while the control area presented $97 \%$. Although the value in the area thinned into savanna was smaller, a greater part of the radiation absorbed was captured by the herbaceous species in the thinned area, while in the control area more was captured by species in 
the shrub-arboreal stratum, and this difference was reflected in the appearance of forage species. Out of the forage species that developed in the area thinned into savanna, Brachiaria plantaginea (Link) Hitch, with a frequency higher than $79 \%$ (Table 1) and an ephemeral cycle with an average duration of 21 days, deserves special mention because it is highly appreciated by animals and is of good nutritive value (SILVA et al., 2011).

There was also a significant difference $(\mathrm{P}<0.05)$ in the LAI variable. Thinning into savanna resulted in plants with the lowest mean LAI, while those in the control area had the highest LAI. The low frequency and low volume of rainfall (Figure 1) promoted a decrease in the leaf area during the evaluated seasons in the area thinned into savanna, as well as in the control area. This is an adaptive response to a lack of water by most species. According to Seddaiu et al. (2013), the presence of the woody component favors the conservation of the soil and improves crop productivity, reducing the impacts of out of season summers.

Table 4. Coverage components, biomass, height, leaf area index, and interception of photosynthetically active radiation of the herbaceous stratum in the Caatinga area thinned into savanna and the unmanipulated (Control) area in Sobral, CE in 2016.

\begin{tabular}{|c|c|c|c|}
\hline Manipulation & Rainy season & Rainy-dry transition season & Mean \\
\hline & \multicolumn{3}{|c|}{ Total soil Coverage $(\%)(\mathrm{CV}=22.73 \%)$} \\
\hline Thinned into savanna & $61.35^{\mathrm{Aa}}$ & $45.83^{\mathrm{Ab}}$ & 53.59 \\
\hline Control & $64.48^{\mathrm{Aa}}$ & $37.92^{\mathrm{Bb}}$ & 51.20 \\
\hline \multirow[t]{2}{*}{ Mean } & 62.92 & 41.88 & \\
\hline & \multicolumn{3}{|c|}{ Herbaceous monocot coverage $(\%)(\mathrm{CV}=150.00 \%)$} \\
\hline Thinned into savanna & $9.85^{\mathrm{Aa}}$ & $0.003^{\mathrm{Ab}}$ & 4.93 \\
\hline Control & $1.77^{\mathrm{Ba}}$ & $0.00^{\mathrm{Aa}}$ & 0.89 \\
\hline \multirow[t]{2}{*}{ Mean } & 5.81 & 0.01 & \\
\hline & \multicolumn{3}{|c|}{ Herbaceous dicot coverage $(\%)(\mathrm{CV}=47.00 \%)$} \\
\hline Thinned into savanna & 45.21 & 39.58 & $42.40^{\mathrm{a}}$ \\
\hline Control & 21.36 & 14.38 & $17.87^{\mathrm{B}}$ \\
\hline \multirow[t]{2}{*}{ Mean } & $33.28^{\mathrm{a}}$ & $26.98^{\mathrm{a}}$ & \\
\hline & \multicolumn{3}{|c|}{ Litter coverage $(\%)(\mathrm{CV}=79.00 \%)$} \\
\hline Thinned into savanna & $6.08^{\mathrm{Ba}}$ & $6.67^{\mathrm{Ba}}$ & 6.37 \\
\hline Control & $41.56^{\mathrm{Aa}}$ & $23.55^{\mathrm{Ab}}$ & 32.55 \\
\hline \multirow[t]{2}{*}{ Mean } & 23.82 & 15.11 & \\
\hline & \multicolumn{3}{|c|}{ Total forage biomass (TFB, $\left.\mathrm{kg} \mathrm{ha}^{-1}, \mathrm{CV}=104.00 \%\right)$} \\
\hline Thinned into savanna & $1,940.55$ & $1,918.55$ & $1,929.75^{\mathrm{A}}$ \\
\hline Control & 78.42 & 37.40 & $57.91^{\mathrm{B}}$ \\
\hline \multirow[t]{2}{*}{ Mean } & $1,009.50^{\mathrm{a}}$ & $978.18^{\mathrm{a}}$ & \\
\hline & \multicolumn{3}{|c|}{ Litter biomass $\left(\mathrm{BL}, \mathrm{kg} \mathrm{ha}^{-1}\right)(\mathrm{CV}=82.00 \%)$} \\
\hline Thinned into savanna & $1,033.33^{\mathrm{Ba}}$ & $170.00^{\mathrm{Ab}}$ & 601.67 \\
\hline Control & $1,777.50^{\mathrm{Aa}}$ & $640.00^{\mathrm{Ab}}$ & $1,206.25$ \\
\hline Mean & $1,402.92$ & 405.00 & \\
\hline
\end{tabular}


continuation

\begin{tabular}{|c|c|c|c|}
\hline \multirow[b]{2}{*}{ Thinned into savanna } & \multicolumn{3}{|c|}{ Height of the herbaceous stratum $(\mathrm{cm})(\mathrm{CV}=87.00 \%)$} \\
\hline & $19.35^{\mathrm{Ab}}$ & $77.96^{\mathrm{Aa}}$ & 48.65 \\
\hline Control & $12.86^{\mathrm{Aa}}$ & $16.04^{\mathrm{Ba}}$ & 14.45 \\
\hline \multirow[t]{2}{*}{ Mean } & 16.11 & 47.00 & \\
\hline & \multicolumn{3}{|c|}{ Leaf area index $(\mathrm{LAI})(\mathrm{CV}=52.41 \%)$} \\
\hline Thinned into savanna & 4.79 & 1.46 & $3.13^{\mathrm{B}}$ \\
\hline Control & 7.04 & 3.14 & $5.10^{\mathrm{A}}$ \\
\hline \multirow[t]{2}{*}{ Mean } & $5.92^{\mathrm{a}}$ & $2.30^{\mathrm{b}}$ & \\
\hline & \multicolumn{3}{|c|}{ Interception of photosynthetically active radiation (IPAR, \%) $(\mathrm{CV}=18.00 \%$} \\
\hline Thinned into savanna & 87.13 & 59.92 & $73.52^{\mathrm{B}}$ \\
\hline Control & 97.25 & 78.92 & $88.10^{\mathrm{A}}$ \\
\hline Mean & $92.19^{\mathrm{a}}$ & $62.42^{b}$ & \\
\hline
\end{tabular}

Means followed by different upper-case letters in the same column and different lower-case letters in the same row for each variable differed significantly according to Tukey's test $(\mathrm{p}<0.05)$.

When a significant interaction was detected, the letters are presented at the center of each variable and not by the mean values, and when no significant interaction was observed the letters are presented only by the mean values.

There were significant differences $(\mathrm{P}<0.05)$ in the variables litter coverage (\%) and litter biomass $\left(\mathrm{kg} \mathrm{ha}{ }^{-1}\right)$, in that plants in the area thinned into savanna had the smallest average values of these variable, while those in the control area had the highest averages (Table 4). This response is due to the presence of a larger number of deciduous trees and shrubs (especially Croton sonderianus Muell.Arg, a shrub that was present at densities of 628 plants ha $^{-1}$ ) (Table 1), which was reflected in patterns of biomass production $\left(\mathrm{kg} \mathrm{ha}^{-1}\right)$. The increase in rainfall during the rainy season created an environment favoring the decomposition of litter. According to Lima et al. (2015), moisture favors the growth of microorganisms that act directly on the decomposition of litter.

The greater coverage in the control area did not allow the heights of herbaceous species to increase. This pattern was strongly influenced by the presence of the species Hyptis suaveolens Link. Poit, which occurred with a frequency of more than $90 \%$ in the area thinned into savanna (Table 1).

The high coefficients of variation (CV) observed in this study could be attributed to the fact that it was carried out in rangeland pasture located in a biome with high biodiversity that was affected by the region's characteristic climatic variation.

\section{Trial 2}

There were significant differences $(\mathrm{P}<0.05)$ between species in the variables total forage biomass production (TFB), dry leaf blade biomass (DLB), number of live leaves per tiller (NLL), and leaf area index (LAI), with massai grass presenting the highest means for these variables (Table 5). Lopes et al. (2014), when evaluating massai grass, observed that it was able to allocate more photoassimilates to its tillers when cultivated in ideal conditions, ensuring good soil structure. Cavalcante et al. (2014) observed that after 90 days of deferring, $2,000 \mathrm{~kg}$ $\mathrm{ha}^{-1}$ of massai grass could be produced, with $90 \%$ of this biomass represented by the green leaf blade fraction. Other benefits that the ideal coverage of the woody stratum brings to the grasses in semiarid regions are: increased nutritional value, since it improves the environment for the soil microbiota, which increases nitrogen mineralization (GUERRA et al., 2016); and improved water use efficiency, as it minimizes the climatic intensity (KASSA et al., 2017). 
The physiological variables evaluated in this study did not differ between grass species $(\mathrm{P}>0.05)$ (Table 5). The fact that they were two plants that used the same photosynthetic system $\left(\mathrm{C}_{4}\right)$ and were subjected to the same conditions of climate and management, as well as the fact that measurements were taken at the same day and time on similar leaves, may have been responsible for this result. The low precipitation in semi-arid regions may influence the physiological processes of plants that regulate the turgor pressure of their cells and stop their vegetative growth, but this is more pronounced if plants of different photosynthetic groups are compared (TAIZ; ZEIGER, 2004). The fact that the two studied grasses did not differ significantly demonstrates that massai grass also presents drought resilience characteristics, mainly in its water use efficiency, which according to Silva et al. (2017) is one of the main characteristics of buffel grass. Because these grasses were cultivated in a region characterized by high climatic variation within the rainy season, the high variation implied by the CVs of the analyzed variables was attributed to these factors.

The grasses inserted in the thinned area, due to their $\mathrm{C}_{4}$ photosynthetic mechanism, used water and captured solar radiation incident on the top of the canopy more efficiently than plants with the $\mathrm{C}_{3}$ mechanism; moreover, the presence of the woody stratum in the area allows the quantum efficiency of photosystems to be improved. Ramos et al. (2018), when evaluating the grass Brachiaria decumbens in different manipulated areas, observed that when the grass was cultivated in an area containing a woody stratum it had a better quantum efficiency (0.82) of photosystem II ( Fv/Fm) than when grown in a deforested area. According to those authors, values lower than 0.75 denote photoinhibitory damage in the PSII reaction centers. Improvements in these indices contribute to the production of forage biomass in the rainy season, which in turn can be used during the dry season. According to Barreto et al. (2010), the unmanipulated Caatinga currently produces only $4,000 \mathrm{~kg} \mathrm{ha}^{-1}$ year $^{-1}$ of dry matter, and only 400 $\mathrm{kg} \mathrm{ha}^{-1}$ of this is available as pasture. In addition, thinning favors increased animal productivity and the improved productive capacity of the soil, which besides reducing the use of agricultural inputs also promotes reduced emissions of pollutants to the atmosphere without reducing biodiversity. Formiga et al. (2012), evaluating buffel grass in a thinned area, observed that when compared to the grass Andropogon gayanus, this species occurred at the highest frequency in the area, and this was associated with its high adaptability. Moreover, it could be inferred that massai grass presented a superior response to that of buffel grass in this study, making it an excellent alternative for use in the production of biomass in the long term, without contributing to the loss of native biodiversity.

Table 5. Structural and physiological variables of massai grass and buffel grass cultivated in a Caatinga area thinned into savanna in Sobral, CE in the rainy season of 2016.

\begin{tabular}{lccccc}
\hline \multicolumn{7}{c}{ Structural } \\
\hline \multicolumn{1}{c}{ Variable } & Massai grass & Buffel grass & Mean & CV (\%) & P-value \\
\hline TFB $\left(\mathrm{kg} \mathrm{ha}^{-1}\right)$ & $3,006.50$ & $1,885.40$ & ----- & 22.60 & 0.0284 \\
DLB $\left(\mathrm{kg} \mathrm{ha}^{-1}\right)$ & $1,920.70$ & 568.30 & ----- & 29.00 & 0.0018 \\
DBS $\left(\mathrm{kg} \mathrm{ha}^{-1}\right)$ & 712.70 & 789.20 & 750.10 & 14.10 & 0.3457 \\
DFB $\left(\mathrm{kg} \mathrm{ha}^{-1}\right)$ & 373.10 & 515.30 & 444.20 & 27.30 & 0.1478 \\
PDT $\left(\right.$ plants $\left./ \mathrm{m}^{2}\right)$ & 550.00 & 350.00 & 450.00 & 17.80 & 0.0549 \\
NLL & $0.09(3.30)$ & $0.07(3.75)$ & ------ & 10.00 & 0.0247 \\
& & & & & continue
\end{tabular}


continuation

\begin{tabular}{|c|c|c|c|c|c|}
\hline IPAR (\%) & $0.40^{\mathrm{a}}$ & $0.70^{\mathrm{a}}$ & 0.55 & 32.40 & $<.0001$ \\
\hline LAI & $2.50^{\mathrm{a}}$ & $0.20^{\mathrm{b}}$ & ------ & 51.00 & 0.0039 \\
\hline Height (cm) & 24.60 & 22.40 & 23.50 & 24.30 & 0.6155 \\
\hline RUE & 7.10 & 4.50 & 5.80 & 25.80 & 0.1270 \\
\hline \multicolumn{6}{|c|}{ Physiological } \\
\hline Variable & Massai grass & Buffel grass & Mean & CV $(\%)$ & P-Value \\
\hline $\mathrm{T}_{\text {leaf }}\left({ }^{\circ} \mathrm{C}\right)$ & 33.40 & 33.50 & 33.50 & 6.50 & 0.9254 \\
\hline $\mathrm{Ci}(\mathrm{ppm})$ & 209.00 & 195.30 & 202.20 & 44.90 & 0.8376 \\
\hline $\mathrm{E}\left(\mathrm{mmol} \cdot \mathrm{m}^{-2} \bullet \mathrm{s}^{-1}\right)$ & 0.90 & 0.60 & 0.80 & 88.10 & 0.6050 \\
\hline $\operatorname{gs}\left(\mathrm{mol} \cdot \mathrm{m}^{-2} \cdot \mathrm{s}^{-1}\right)$ & 0.10 & 0.10 & 0.10 & 104.90 & 0.4743 \\
\hline $\mathrm{A}\left(\mu \mathrm{mol} \cdot \mathrm{m}^{-2} \cdot \mathrm{s}^{-1}\right)$ & 4.20 & 4.60 & 4.40 & 60.40 & 0.8408 \\
\hline SPAD & 25.10 & 27.80 & 26.50 & 15.70 & 0.3934 \\
\hline $\mathrm{A} / \mathrm{Ci}$ & 0.02 & 0.04 & 0.03 & 119.70 & 0.4100 \\
\hline $\mathrm{A} / \mathrm{E}$ & 6.70 & 6.50 & 6.60 & 53.30 & 0.9304 \\
\hline
\end{tabular}

Means followed by the same lowercase letter in the same row did not significantly differ according to Tukey's test ( $\mathrm{P}>0.05)$. The variable number of live leaves per tiller (NLL) was transformed by the equation: $\mathrm{Y}=\mathrm{Y}^{-2}$. The numbers in parentheses and in italics represent the original values of the estimates.

Abbreviations: total forage biomass (TFB); dry leaf biomass (DLB); dry biomass of green stem (DBS); dry forage biomass (DFB); population density of tillers (PDT); leaf area index (LAI); interception of photosynthetically active radiation (IPAR); rainfall use efficiency (RUE); internal leaf temperature $\left(\mathrm{T}_{\text {leaf }}\right)$; internal concentration of carbon dioxide $(\mathrm{Ci})$; leaf transpiration rate $(\mathrm{E})$; stomatal conductance (gs); photosynthetic rate (A); relative index of chlorophyll a and b (SPAD); rate of carboxylation (A/Ci); and intrinsic water use efficiency $(\mathrm{A} / \mathrm{E})$.

When a significant effect was detected, the letters are presented to the left of the means in the table.

\section{Conclusions}

Thinning is a viable way to intensify management and increase forage production in the Caatinga, as it favors quantitative increases in forage biomass and the abundance of native herbaceous species, including both mono- and/or dicotyledonous species, while also allowing for the use of exotic species to improve the herbaceous stratum and increasing the production of forage even further. This was reflected in the observed increase in the support capacity of the area without compromising the biodiversity of the exploited biome.

\section{Acknowledgements}

Thanks are given to the Brazilian Agricultural Research Corporation (EMBRAPA Goats and Sheep) for supporting this research, as well as to the Federal University of Ceará, the Animal Science
Graduate Program, and CAPES for granting a master's scholarship to the authors.

\section{References}

AGUIAR, M. I.; FIALHO, J. S.; ARAÚJO, F. C. S.; CAMPANHA, M. M.; OLIVEIRA, T. S. Does biomass production depend on plant community diversity? Revista Agroforestry Sytems, Dordrech, v. 87, n. 3, p. 699-711, 2013.

AGUIAR, M. I.; FIALHO, J. S.; CAMPANHA, M. M.; OLIVEIRA, T. S. Carbon sequestration and nutrient reserves under different land use systems. Revista Árvore, Viçosa, MG, v. 38, n. 1, p. 81-93, 2014.

ALVES, J. J. A.; ARAÚJO, M. A.; NASCIMENTO, S. S. Degradação da Caatinga: uma investigação ecogeográfica. Revista Caatinga, Mossoró, v. 22, n. 3, p. 126-135, 2009.

ANGIOSPERM PHYLOGENY GROUP - APG. An update of the Angiosperm Phylogeny Group classification for the orders and families of flowering plants: APG III. 
Botanical Journal of the Linnean Society, Oxford, v. 161, n. 2, p. 105-121, 2009.

ARAÚJO FILHO, J. A.; CARVALHO, F. C.; GARCIA, R.; SOUSA, R. A. Efeitos da manipulação da vegetação lenhosa sobre a produção e compartimentalização da fitomassa pastável de uma Caatinga sucessional. Revista Brasileira de Zootecnia, Viçosa, MG, v. 31, n. 1, p. 1119, 2002

ARAÚJO, L. D. A.; QUIRINO, Z. G. M.; MACHADO, I. C. Fenologia reprodutiva, biologia floral e polinização de Allamanda blanchetti, uma Apocynaceae endêmica da Caatinga. Revista Brasileira de Botânica, São Paulo, v. 34, n. 2, p. 211-222, 2011.

BARRETO, H. F. M.; SOARES, J. P. G.; MORAIS, D. A. E. F.; SILVA, A. C. C.; SALMAN, A. K. D. Impactos ambientais do manejo agroecológico da Caatinga no Rio Grande do Norte. Revista Pesquisa Agropecuária Brasileira, Brasília, v. 45, n. 10, p. 1073-1081, 2010.

BARTHRAM, G. T. Experimental tecniques: the HFRO sward stick. Penicuik: Hill Farming Research Organization, 1986. p. 29-30. (Biennal Report, 19841985).

CAMPANHA, M. M.; ARAÚJO, F. S.; MENEZES, M. O. T.; SILVA, V. M. A.; MEDEIROS, H. R. Estrutura da comunidade vegetal arbóreo-arbustiva de um sistema agrossilvipastoril, em Sobral-CE. Revista Caatinga, Mossoró, v. 24, n. 3, p. 94-101, 2011.

CAMPELO, D. H.; LACERDA, C. F.; SOUSA, J. A.; CORREIA, D.; BEZERRA, A. M. E.; ARAÚJO, J. D. M.; NEVES, A. L. R. Trocas gasosas e eficiência do Fotossistema II em plantas adultas de seis espécies florestais em função do suprimento de água no solo. Revista Árvore, Viçosa, MG, v. 39, n. 5, p. 973-983, 2015.

CAVALCANTE, A. C. R.; ARAÚJO, J. F.; CARNEIRO, M. S. S.; SOUSA, H. A.; TONUCCI, R. G.; ROGERIO, M. C. P.; VASCONCELOS, E. C. G. Potential use of tropical grass for deferment in semi-arid region. American Journal of Plant Sciences, Madinson, v. 5, n. 7, p. 907-914, 2014.

COMISSÃO DE FERTILIDADE DO SOLO DO ESTADO DE MINAS GERAIS - CFSEMG. Recomendações para o uso de corretivos e fertilizantes em Minas Gerais - $5^{\text {a }}$ aproximação. Viçosa, MG: UFV, 1999. $359 \mathrm{p}$.

FORMIGA, L. D. A. S.; PEREIRA FILHO, J. M.; SILVA, A. M. A.; OLIVEIRA, N. S.; SOARES, D. C.; BAKKE, O. A. Forage supply in thinned Caatinga enriched with buffel grass (Cenchrus ciliares L.) grazed by goats and sheep. Revista Acta Scientiarum, Maringá, v. 34, n. 2, p. 189-195, 2012.
FREITAS, A. D. S.; SILVA, T. O.; MENEZES, R. S. C.; SAMPAIO, E. V. S. B.; ARAÚJO, E. R.; FRAGA, V. S. Nodulação e fixação de nitrogênio por forrageiras da caatinga cultivadas em solos do semiárido paraibano. Revista Brasileira de Zootecnia, Viçosa, MG, v. 40, n. 9, p. 1856-1861, 2011.

GUERRA, C. R. S. B.; MORAES, M. L. T.; RECCO, C. R. S. B.; SILVA, C. L. S. P.; GIMESES, F. M. A. Forage yield and nutritive value of naturally growing Brachiaria decumbens as undergrowth to na aroeira tree stand in a silvopasture system. African Journal of Agricultural Research, Lagos, v. 11, n. 40, p. 3922-3928, 2016.

KASSA, H.; DONDEYNE, S.; POESEN, J.; FRANKL, A.; NYSSEN, J. Impact of deforestation on soil fertility, soil carbon and nitrogen stocks: the case of the Gacheb catchment in the White Nile Basin, Ethiopia. Revista Agriculture, Ecosystems and Environment, Amsterdam, v. 247, p. 273-282, 2017.

LIMA, I. L. P.; SCARIOT, A.; GIROLDO, A. B. Impacts of the implementation of silvopastoral systems on biodiversity of native plants in traditional community in the Brazilian Savanna. Revista Agroforestry Systems, Dordrech v. 91, n. 6, p. 1069-1078, 2017.

LIMA, R. P.; FERNANDES, M. M.; FERNANDES, M. R. M.; MATRICARDI, E. A. P. Aporte e decomposição da serrapilheira na Caatinga no Sul do Piauí. Revista Floresta e Ambiente, Rio de Janeiro, v. 22, n. 1, p. 42-49, 2015.

LOPES, M. N.; CÂNDIDO, M. J. D.; POMPEU, R. C. F. F.; SILVA, R. G.; LACERDA, C. F.; BEZERRA, F. M. L. Características morfogênicas de dois tipos de perfilhos e produção de biomassa do capim-massai adubado com nitrogênio durante o estabelecimento. Revista Bioscience Journal, Uberlândia, v. 30, n. 5, p. 666-667, 2014.

MARSHALL, V. M.; LEWIS, M. M.; OSTENDORF, B. Buffel grass (Cenchrus ciliares) as an invader and threat to biodiversity in arid environments: a review. Journal of Arid Environments, London, v. 78, n. S/N, p. 1-12, 2012.

MENDES, M. M. S.; LACERDA, C. F.; FERNANDES, F. E. P.; CAVALCANTE, A. C. R.; OLIVEIRA, T. S. Ecophysiology of deciduous plants grown at different densities in the semiarid region of Brazil. Revista Theoretical and Experimental Plant Physiology, Campo dos Goytacazes, v. 25, n. 2, p. 94-105, 2013.

PEREIRA FILHO, J. M. P.; SILVA, A. M. A.; CÉZAR, M. F. Manejo da Caatinga para a produção de caprinos e ovinos. Revista Brasileira de Saúde e Produção Animal, Salvador, v. 14, n. 1, p. 77-90, 2013.

PEREIRA FILHO, J. M.; ARAÚJO FILHO, J. A.; CARVALHO, F. C.; REGO, M. C. Disponibilidade de 
fitomassa do estrato herbáceo de uma Caatinga raleada submetida ao pastejo alternado ovino-caprino. Livestock Research for Rural Development, Cali, v. 19, n. 1, p. 19002, 2007.

RAMOS, L. M.; REIS, F. O.; CATUNDA, P. H. A.; SOUSA, E. H. S.; NETTO, A. T. Ecophysiology of Brachiaria decumbens in grazing systems. Revista de Ciências Agrárias, Lisboa, v. 41, n. 3, p. 783-788, 2018.

RODAL, M. J. N.; SAMPAIO, E. V. S. B.; FIGUEIREDO, M. A. Manual sobre métodos de estudos florísticos e fitossociológicos: ecossistemas Caatinga. Brasília. Ed. Brasília SB, 2013. 37 p.

SCHACHT, W. H.; MALECHEK, J. C. Nutrition of goats as influenced by thinning and clearing of deciduous woodland in Northeastern Brazil. Journal of Animal Science, Savoy, v. 67, n. 10, p. 2487-2497, 1989.

SEDDAIU, G.; PORCU, G.; LEDDA, L.; ROGGERO, P. P.; AGNELLI, A.; CORTI, G. Soil organic matter content and composition as influenced by soil management in a semi-arid Mediterranean agro-silvo-pastoral system. Revista Agriculture, Ecosystems and Environment, Amsterdam, v. 167, p. 1-11, 2013.

SILVA, C. P.; MENDE FILHO, P. F. M.; GOMES, V. F. F.; MARTINS, C. M.; CUNHA, C. S. M.; LOBATO, M. G. R. Glomlin-related soil protein content in areas of degraded and revegetated Caatinga in the municipality of Irauçuba. Journal of Agriculture Science, Ottawa, v. 10, n. 1, p. 302-312, 2018.

SILVA, J. F.; HONORATO, A. C.; QUEIROZ, M. A. A.; COSTA, M. M.; YANO-MELO, A. M. Morphogenic, structural, and productive characteristics of Cenchrus ciliares L. grown using diferent levels of caprine and ovine biofertilizer. Semina: Ciências Agrárias, Londrina, v. 38, n. 1, p. 355-368, 2017.

SILVA, M. G. S.; LIRA, M. A.; SANTOS, M. V. F.; DUBEUX JUNIOR, J. C. B.; LINS, M. M.; SILVA, C. V. N. S. Dinâmica da associação de capim-milhã e capim-de-raiz em pasto diferido. Revista Brasileira de Zootecnia, Viçosa, MG, v. 40, n. 11, p. 2340-2346, 2011.

SOUZA, V. C.; AGRA, P. F. M.; ANDRADE, L. A.; OLIVEIRA, I. G.; OLIVEIRA, L. S. Germination of seeds of the invasive plant Sebasnia virgata (Cav.) Pers. under effects of light, temperature, and dormancy overcoming. Semina: Ciências Agrárias, Londrina, v. 31, n. 4, p. 889-894, 2010.

STATISTICAL ANALYSIS SYSTEM INTITUTE SAS/STAT. User's guide, Cary:SAS Institute Inc., 2005.

TAIZ, L.; ZEIGER, E. Fisiologia vegetal. 3. ed. Porto Alegre: Artmed, 2004. 719 p.

TILMAN, D.; KNOPS, J.; WEDIN, D.; REICH, P.; RITCHIE, M.; SIEMANN, E. The influence of functional diversity and composition on ecosystem processes. Science, Washington, v. 277, p. 1300-1302, 1997.

TURNER, N. C. Agronomic options for improving rainfall-use efficiency of crops in dryland farming systems. Journal of Experimental Botany, Oxford, v. 55, n. 407, p. 2413-2425, 2004.

VEGA, A.; VALIENTE, O. L.; OLMOS, G.; PÉREZCALVO, E. Use of barley crops, and combinations of lucerne and wimmera grass, as pasture for grazing sheep in the semiarid zones of Spain. Revista Animal Production Science, Clayton, v. 57, n. 10, p. 1071, 2017. 
